\title{
Thresholds for taking antihypertensive drugs in different professional and lay groups: questionnaire survey
}

\author{
Nick Steel
}

School of Health Policy and Practice, University of East Anglia, Norwich NR4 7TJ

Nick Steel health services research fellow nick.steel@ enorfolk-ha.anglox nhs.uk

BMJ 2000;320:1446-7
Hypertension is a common risk factor for cardiovascular disease, but patients' compliance with medication is low. Patients may be less likely to take antihypertensive drugs if they have accurate information about their levels of risk. ${ }^{1}$ Doctors who estimate the risk more accurately are less likely to recommend treatment. ${ }^{2}$ It is not known whether a patient's professional background affects his or her threshold for complying with treatment.

The study compared the threshold at which consultant physicians, general practitioners, nurses attached to a general practice, and the general population would start taking antihypertensive drugs.

\section{Participants, methods, and results}

A postal questionnaire asked whether or not respondents would take drugs if one life would be saved for every $12,33,50,100$, or 250 people treated for five years. This gave six thresholds of numbers needed to treat $(<12$ to 250$)$.

A pilot study showed that a sample size of 28 in each group would have $80 \%$ power to detect a probability of 0.284 that the number needed to treat for nurses is lower than for general practitioners, using a Wilcoxon (Mann-Whitney) rank sum test for ordered categories with two sided significance of 0.05 . To allow for low response rates, all 39 consultant physicians at the city hospitals were recruited. Altogether 39 practice nurses, 39 general practitioners, and 100 adult members of the public were selected from the lists of the local health authority, with systematic sampling from a random starting point. A lower response rate was expected from the public. The local research ethics committee approved the study.

The response rate was $69 \%(149 / 217)$. The threshold for numbers needed to treat chosen by consultant physicians (100) was twice that chosen by general practitioners (50) and three times that chosen by nurses and the public (33) (table). The range of responses within each group was wide, but the difference between the median levels of benefit chosen by the groups was significant $(\mathrm{P}=0.003$, Kruskal-Wallis test). Logistic regression to control for age and sex, with the outcome chosen to be whether or not the number needed to treat was 50 or greater, also showed a significant overall difference between the groups $(P=0.005)$. The adjusted odds ratio for a nurse rather than a consultant choosing a number needed to treat below 50 was 12.5 (95\% confidence interval 2.9 to 50 ).

\section{Comment}

Treating hypertension entails combining evidence with judgment about risk. This study shows how people's risk judgments differ. The questionnaire posed a hypothetical question. The thresholds chosen by the groups might depend on whether the question was real or hypothetical, or whether the benefits were expressed as reduction of absolute risk (such as numbers needed to treat) or relative risk. Because all groups faced the same question, however, valid comparisons can be made between them. The moderate response rate from members of the public (58\%) is a possible source of bias.

The questionnaire referred to reduction in mortality rather than morbidity. Death as an outcome is easier to understand and less subject to interpretation than non-fatal cardiovascular events. For adults aged 60 years or over treatment reduces the absolute risk of both mortality and morbidity by a similar amount. The number needed to treat to prevent one death is about 50 , the number chosen by general practitioners. ${ }^{3}$ For younger adults there is little evidence for a reduction in mortality, but the number needed to treat to prevent one stroke over five years is about $170{ }^{4}$

The 1999 guidelines of the British Hypertension Society (written largely by professors) recommend starting treatment on the basis of risk rather than blood pressure. ${ }^{5}$ This will encourage doctors to make

\begin{tabular}{|c|c|c|c|c|}
\hline Variable & $\begin{array}{l}\text { Members of the public } \\
(\mathrm{n}=100)\end{array}$ & $\begin{array}{l}\text { Practice nurses } \\
\quad(\mathrm{n}=39)\end{array}$ & $\begin{array}{c}\text { General practitioners } \\
(\mathrm{n}=39)\end{array}$ & $\begin{array}{c}\text { Consultant } \\
\text { physicians }(\mathrm{n}=39)\end{array}$ \\
\hline No (\%) responding & $58(58)$ & $32(82)$ & $30(77)$ & $29(74)$ \\
\hline \multicolumn{5}{|l|}{ Age group by No (\%): } \\
\hline$<40$ years & $14(25)$ & $15(47)$ & $(47)$ & $7(24)$ \\
\hline $41-65$ years & $25(45)$ & $16(50)$ & (53) & $22(76)$ \\
\hline$>65$ years & $17(30)$ & $1(3)$ & (0) & $0(0)$ \\
\hline Ratio of men:women (\%) & $42: 58$ & 3:97 & $70: 30$ & $86: 14$ \\
\hline $\begin{array}{l}\text { Odds ratio }(95 \% \mathrm{Cl}) \text { adjusted for age and sex, with } \\
\text { consultants as reference group }\end{array}$ & $0.12(0.03$ to 0.42$)$ & $0.08(0.02$ to 0.35$)$ & $0.27(0.08$ to 0.96$)$ & \\
\hline \multicolumn{5}{|l|}{ Median NNT threshold chosen (interquartile range): } \\
\hline$<40$ years & 50 & 33 & 50 or 100 & 250 \\
\hline $41-65$ years & 12 & 12 or 33 & 33 & 50 \\
\hline$>65$ years & 50 & 33 & & \\
\hline Men & 50 & 33 & 50 & 100 \\
\hline Women & 33 & 33 & 50 & 250 \\
\hline All respondents & $33(12-250)$ & $33(<12-50)$ & $50(33-100)$ & $100(50-250)$ \\
\hline
\end{tabular}


explicit judgments of risk. Clinicians should not assume that their patients and professional colleagues are likely to share their opinion whether treatment for hypertension is worth while.

I thank all the people who took part in this study, Brian Tom from the Centre for Applied Medical Statistics at Cambridge University for statistical advice, and Peter Brambleby and Malcolm Adams for their constructive comments.

NS is the sole author and acts as guarantor of the study.

Funding: NS was supported by a health services research fellowship from the NHS Executive Anglia and Oxford Research and Development Directorate.

Competing interests: None declared.
1 Reed WW, Herbers JE, Noel GL. Cholesterol-lowering therapy: what patients expect in return.J Gen Intern Med 1993;8:591-6.

2 Friedmann PD, Brett AS, Mayo-Smith MF. Differences in generalists' and cardiologists' perceptions of cardiovascular risk and the outcomes of preventive therapy in cardiovascular disease. Ann Intern Med 1996;124: 414-21.

3 Mulrow C, Lau J, Cornell J, Brand M. Antihypertensive drug therapy in the elderly. Cochrane Collaboration. Cochrane Library, Issue 1; Oxford: Update Software, 1998.

4 Guevffier F, Froment A, Gouton M. New meta-analysis of treatment trials of hypertension: improving the estimate of therapeutic benefit. J Hum Hypertens 1996;10:1-8.

5 Ramsay LE, Williams B, Johnston GD, MacGregor GA, Poston L, Potter $\mathrm{JF}$, et al. British Hypertension Society guidelines for hypertension management 1999: summary. BMJ 1999;319:630-5.

(Accepted 13 December 1999)

\title{
Aggression and violent behaviour in general practice: population based survey in the north of England
}

\author{
Graham J Ness, Allan House, Andrew R Ness
}

Three studies, the last one eight years ago, have suggested that general practitioners in the United Kingdom are frequently subjected to verbal abuse, with an estimated annual frequency of such incidents of between $25 \%$ and $59 \% .{ }^{1-3}$ In one of these studies $5 \%$ of general practitioners reported having been threatened with a weapon in the preceding year ${ }^{3}$; annual rates of physical injury ranged from $1 \%$ to $11 \% .^{1-3}$ These three studies, and subsequent discussion, raised concern that aggression towards general practitioners was becoming more common. To estimate accurately the current frequency of such incidents we undertook a survey of general practitioners working in a health authority in the north of England.

\section{Subjects, methods, and results}

During May to September 1997 we sent a brief questionnaire to all 419 general practice principals in the area administered by Leeds Health Authority. Principals were asked to recall their experiences of aggression directed at themselves at work over the previous year in four categories: verbal abuse, specific threats, physical action without injury, and serious incidents (including threats with a weapon or attacks leading to physical injury). We obtained the Jarman index ${ }^{4}$ for each electoral ward. This showed the percentage of patients attracting deprivation payments on that practice's list. The score was used to classify practices as high or low deprivation according to whether the percentage was above or below the median for the sample.

Completed questionnaires were returned by 380 (91\%) principals (244 men, 136 women). The table shows the numbers of respondents who experienced any of the four categories of aggression and the incidence of aggression by deprivation. A higher proportion of women than men reported experiencing verbal abuse, but a higher proportion of men than women reported physical contact abuse or a serious incident. A higher proportion of doctors in the high deprivation practices reported aggression than doctors in the low deprivation practices.

One doctor was involved in an incident that resulted in minor physical injury, and in five incidents doctors were threatened with a weapon. Two of these incidents involved patients described as psychotic at the time of the attack; a further three involved a patient with an alcohol or substance misuse problem.
School of Health and Related Research, University of Sheffield, Sheffield S1 4DA Graham J Ness clinical lecturer in forensic psychiatry

Academic Unit of Psychiatry and Behavioural Sciences, Leeds LS2 9LT

Allan House professor in liaison psychiatry

continued over

BMJ 2000;320:1447-8

Reported aggression at work towards 380 general practitioners covering the population of Leeds Health Authority during 1997

\begin{tabular}{|c|c|c|c|c|c|c|c|c|}
\hline \multirow[b]{2}{*}{ Respondents } & \multicolumn{2}{|c|}{ Verbal abuse } & \multicolumn{2}{|c|}{ Specific threats } & \multicolumn{2}{|c|}{ Physical action } & \multicolumn{2}{|c|}{ Serious incidents } \\
\hline & $\begin{array}{l}\text { No of } \\
\text { respondents }\end{array}$ & $\begin{array}{c}\% \text { of respondents } \\
(95 \% \mathrm{CI}))\end{array}$ & $\begin{array}{c}\text { No of } \\
\text { respondents }\end{array}$ & $\begin{array}{l}\% \text { of respondents } \\
(95 \% \mathrm{Cl})\end{array}$ & $\begin{array}{c}\text { No of } \\
\text { respondents }\end{array}$ & $\begin{array}{l}\% \text { of respondents } \\
(95 \% \mathrm{Cl})\end{array}$ & $\begin{array}{c}\text { No of } \\
\text { respondents }\end{array}$ & $\begin{array}{l}\% \text { of respondents } \\
(95 \% \mathrm{Cl})\end{array}$ \\
\hline All & 205 & 54 (49 to 59$)$ & 108 & 28 (24 to 33 ) & 24 & $6(4$ to 9$)$ & 6 & $1.6(0.7$ to 3.4$)$ \\
\hline Male $(n=244)$ & 121 & 50 (43 to 56$)$ & 63 & 26 (21 to 32 ) & 17 & 7 (4 to 11$)$ & 5 & $2.0(0.8$ to 4.7$)$ \\
\hline Female $(n=136)$ & 84 & 62 (53 to 70$)$ & 45 & 33 (26 to 41$)$ & 7 & $5(3$ to 10$)$ & 1 & $0.7(0.1$ to 4.1$)$ \\
\hline Relative risk (male $v$ female) & & $1.3(1.0 \text { to } 1.5)^{\star}$ & & $1.3(0.9$ to 1.8$)$ & & $0.7(0.3$ to 1.7$)$ & & 0.4 (0.04 to 3.04$)$ \\
\hline $\begin{array}{l}\text { High deprivation practices } \\
(\mathrm{n}=181)\end{array}$ & 119 & 66 (59 to 72$)$ & 71 & 39 (32 to 47$)$ & 18 & 10 (6 to 15$)$ & 5 & 2.8 (1.2 to 6.3$)$ \\
\hline $\begin{array}{l}\text { Low deprivation practices } \\
(\mathrm{n}=199)\end{array}$ & 86 & 43 (37 to 50$)$ & 37 & 19 (14 to 25$)$ & 6 & 3 (1 to 6$)$ & 1 & 0.5 (0.09 to 2.8$)$ \\
\hline $\begin{array}{l}\text { Relative risk (more } \\
\text { deprived/less deprived) }\end{array}$ & & $1.5(1.3 \text { to } 1.8)^{\star *}$ & & $2.1(1.5 \text { to } 3.0)^{\star *}$ & & $3.3(1.3 \text { to } 8.1)^{*}$ & & $5.5(0.7$ to 46.6$)$ \\
\hline
\end{tabular}

${ }^{\star} \mathrm{P}<0.05$, ${ }^{*} \mathrm{P}<0.001$ (calculated by using $\chi^{2}$ test or Fisher's exact test).

tCalculated by using the technique described by Wilson. 